\title{
Analysis of SOEs' Bankruptcy Reorganization: A Case Study of Nuclear Titanium Dioxide Company
}

\author{
Jia $Y i^{1,}$ a \\ ${ }^{1}$ The Alberta School of Business, University of Alberta, Edmonton T6G 2R3, Canada \\ acaissayi@gmail.com
}

Keywords: SOE, bankruptcy reorganization, risks and benefits.

\begin{abstract}
This paper focus on the risks and benefits of implementing bankruptcy reorganization of the state-owned enterprises (SOE). By using the nuclear dioxide company as an example, this paper will discuss the bankruptcy reorganization's impact on different parties involved in this company including the creditor, the debtor, the employers, big shareholders and small shareholders. By executing the bankruptcy reorganization, the nuclear titanium dioxide company went back to normal from serious financial crisis. The successful results are mainly because of the compromise of different interest parties. As a result of the overhaul, all parties' interest involved in this firm have been well protected.
\end{abstract}

\section{Introduction}

The nuclear titanium dioxide company is used in this article since it is one typical example of Chinese stated-owned company which gradually went to financial crisis because of mangers' mismanagement, outdated company operation strategies and talented employers who refused to accept the change of new market environment when China transferred from planned economy to market economy. By implementing the bankruptcy reorganization, the nuclear titanium dioxide company went back to normal and achieved a great reputation in the market again.

This paper is organized as follows, first part is the background why the bankruptcy reorganization will be implemented, and the following paragraphs will discuss the strategies' impact on different parties involved in this company: benefits and risks for company who bought the "shell company; benefits and risks for the creditors; benefit and risks for stock holders; and how employers would affect the company overhaul. Finally, the paper will summarize the impact of the bankruptcy reorganization and point out the conclusion.

\section{Background}

Worked as an essential part of plan economy, state-owned companies are more like manufacturing platforms than like real companies before 1979. The "open door" economy policy executed by Chinese government in 1979 strongly affected the process of reform of state-owned enterprises. This paper will focus on state-owned enterprises reform after 1990. Military Enterprises were an important part of the national strategic industry. They were not only important industrial and technological foundations for national defense modernization, but also driving forces for the development of national economy and technology. The military industry reorganization started from 1978. The first overhaul period was from 1978 to 1998, lots of stated owned military enterprises became private companies during that period. Nuclear titanium dioxide company was one of those companies. (Song, Han, 2008). Founded in 1989, nuclear titanium dioxide company was the first one of those companies which introduced foreign advanced technology and equipment to China. Nuclear Titanium Dioxide Company had a very good performance when China was still in planned economy. However, it failed to catch up with the rapid market change and economic development when China gradually changed from planned economy to market economy. Liu. (2015)

Many reasons triggered the state-owned companies to lose their economy position. Using nuclear titanium dioxide company as a typical example, this paper is going to list those reasons in following 
content. First, China transferred from planned economy to market economy in 1992. Under planned economy, company managers did not have the management autonomy. The amount of product stateowned company produced was according to government regulations. Employers only had to care about how much they must produce to fulfill their production requirement rather than how much they needed to sell to be profitable. Second, from 1978, competitions were largely growing after the "open world" economy policy executed. State-owned enterprises started to be reformed when the common trend was privatization during that period. Market economy began to make some impact. Lin. (2004). State-owned companies transferred from controlled by solely planned economy to dual manipulated by planned economy and market economy. Private companies, which were completely forbidden in China before the "open door" policy was executed, were becoming one important part in the economy after 1978. Lin. (2004). Third, China gradually entered the international market. The multiplication of the sources of external investment funds were also improving the competitions stated-owned companies faced. Fourth, reform took place when China was facing a high speed economic growth. Regarding to the nuclear titanium dioxide company, the price of titanium plumped after the financial crisis in 2008, whole titanium industry was sluggish during that period. As a result of bad economy environment and manager's mismanagement, nuclear titanium dioxide company made continuously capital loss, facing delisting risk and bankruptcy risk. Ordinary people impression regarding to statedowned company were also not as good during those years. General public's common impressions of stated owned company after "open door" policies were that they were as not open and transparent as people expected, and that those companies might be big obstacles when China decided to gradually change from planned economy to market economy, and that they were normally operated by long term mismanagement.

State owned companies began to reform from 1978 and developed rapidly ever since. "Bankruptcy Reorganization" is a new concept which was developed in new 《Company Bankruptcy Law》. This law is mainly created by the court to help company which was in bad financial situation to implement business reorganization and debt reorganization if different parties involved in this firm appeal to the court. The policy aims to help companies to get away from the financial crisis and return their business ability. Xia (2016). Regarding to the nuclear titanium dioxide company, this company faced big challenge after 2008. In 2009, this nuclear company was threatened to a full-blown crisis. One previous employer from the company narrated, "Company was facing capital loss year by year from 2008 to 2010. In the End, the present value of company dropped from 1billion to 100million." Main sceneries happened during that periods: company was not able to pay salaries; workers protested; lots of raw materials and equipment were "missing". If not choosing to overhaul, the company would soon become bankruptcy. Thus, Nuclear Titanium Dioxide Company started to look for help from financial market and private sector. However, in 2010, all asset restructuring and custody failed bring Nuclear Titanium Dioxide Company back to life. April 22nd, 2011, company creditors decided to apply for bankruptcy reorganization in Jia Yu Guan intermediated people's court. In July 29th, Nuclear Titanium Dioxide Company held an open shareholder selection. They decided to choose Anhui Venus Titanium Dioxide (Group) Co., Ltd. (hereinafter referred to as Venus Titanium) to manage them. And in November 30th, Jia Yu Guan intermediate people's court accepted this case. Financial Advisor Mei Zheng, Xu was responsible for this bankruptcy reorganization. In that period, Mei Zheng, Xu concluded that there would be two options to process the company overhaul. Those two options are bankruptcy liquidation and bankruptcy reorganization (Wang, Cao, Zhang 2011). Regarding to the first option bankruptcy liquidation, nuclear titanium dioxide, a listed company, has its most important "shell recourse". So normally financial advisors would withdraw all the assets from the listed company and introduce top companies in this industry to buy the "company shell". The post reform company would go to the stock market again. This method normally called "backdoor listings". However, the second approach bankruptcy reorganization, which Mei Zheng, Xu finally decided to use, believed that the combination of company restructuring and management reforming would be able to solve this crisis, this method is called combined debt restructuring. Through introducing top companies within the industry; equity restructuring and asset restructuring; debt restructuring and acquisitions. This nuclear company went back to normal after few years' overhaul. 


\section{Benefits and Risks for Different Parties}

\section{Benefits and Risks for the Company Who Bought the "Shell Company"}

The main purpose of a private company who participated in the company reorganization is to buy a "shell" to be listed. Reverse merger is able to help company to go to the public without IPO. Feldman. (2006). There are lots of advantages to go to the stock market through reverse merger.

First, easier and faster. The legal procedure of buying a "shell" is easier than that of using IPO to go to the stock market. A company who wants to process IPO would have to pass a very complex listing approval process.

Thus, the transaction can be completed very quickly by "buying shell". If operated well, the company only need around three to nine months processing time to go to stock market. If a company want to IPO, on the other hand, they need around one to two years. Second, Existence of shareholder base. The more shareholders in the company generally means the more active shareholders trading in the stock and the less volatile the stock prices from ordinary buying and selling pressure. Existing shareholders are often an overlooked but great source of capital raise via shareholder rights offerings. Previous trading histories, although really any pre-reverse merger trading history should not be indicative of future. Those does show how active the public vehicle shareholder base is. Statistics shows that it is infinitely easier for an active trading market to develop where one has previously existed. Third, going to the public. Since a reverse merger is a going public transaction the newly public vehicle or newly public company will have all the benefits of being public, including the ability to use stock and stock options to attract and keep senior executives. Feldman. (2006).

However, there exists lots of risks regarding company reorganization. First, the cost of the bankruptcy reorganization is extremely high and the reform company need to be highly qualified. In the case of nuclear titanium dioxide company, Jian Feng, Li was the largest shareholder and the chairmen in nuclear titanium dioxide company who owned $15.7 \%$ of the shareholding in this firm. Jian Feng, Li who proposed to use around 20 million RMB in his previous plan used more than 100million RMB in reality. In order to guarantee the company can operate smoothly afterwards, in addition to pay for the bank borrowing, two main shareholders in nuclear titanium dioxide company also paid out around 20million to increase liquidation proportion of small amount bond holders from $40 \%$ to $70 \%$.

Besides, restructuring parties confronts intense conflict with the staffs especially those of stateowned enterprises. Those workers who started to work century 60-70 were mostly worked under the planned economy. They donated their whole life in those state-owned enterprise and felt hard to get used to the company reorganization. First, they strongly believed in outdated ideas and are highly dependent, refusing to make any changes. They thought their wages should always increase. They had outdated industry knowledge, their ability to accept new knowledge is not as good as young people. State-owned enterprises used to implement a "one-man system" under planned economy, workers who only needed to be responsible for his own work cannot understand the process before and after what he did. They could not understand the relevant skills and they thought they would have one permanent job during their whole life. Second, those previous employers convinced that state-owned enterprises would not collapse. As long as the state-owned company was not acquainted by private companies, they could be incorporated into other state-owned enterprises. That was why previous workers were strongly resistance to private enterprises to get involved, the reform company were difficult to carry out their reform and merger plans. In the case regarding nuclear titanium dioxide company, Jian Feng, Li faced lots of protests and rejections from the previous workers. In the middle of the reform, some previous worker even wrote a letter of complaint that Jian Feng, Li was incompetent of implementing this reform. Jian Feng, Li finally properly solved those previous employer's voice of oppositions and successfully completed the enterprise reform. Last but not the least, Regional state-owned enterprises are major financial resources for the local government. Those companies could also offer employment opportunities. Thus, Government paid strong attention on the reorganization process. In the case of the nuclear titanium dioxide company, Local government often operated investigation during the reform, Jian Feng, li could feel that local governments distrust him and those distrust can contribute to unease and resistance. However, He also recognized that he 
need the support from the government regarding water and electricity supply. After balanced his relationship with the local government and things he needed to complete to process the reform. He successfully turned the company back to life.

\section{Benefits and Risks for the creditors}

Regarding to the company owner, there are benefits and risks. This part will discuss the benefits and risks confronted by the company owner. First, we present the benefits bankrupt companies can achieve if they are willing to start the bankruptcy reorganization.

First, Bankruptcy reorganization can protect the interests of all parties, helping them to achieve win-win result. Regarding to debtor insolvency, if the debtor chooses to go bankruptcy liquidation procedure without any financial activities, the creditor's claim rate will be extremely low. This method will be threat to the interest of creditors and investors. On the other hand, if the creditors, investors and debtors reach a consensus on company reorganization, each party of them make some sacrifice and they can also introduce financial fund from the reform company. As a result, the compensate rate of debtors will be expected to increase significantly. In terms of the nuclear titanium dioxide company, the supplier of the titanium dioxide which sold lots of products on account, its money issue was highly affected by if the reorganization plan can be successfully achieved. If the company stopped to produce, the supplier's chance of ask the money back would become really low. To solve this problem, after the company applied the bankruptcy reorganization policies, they finally set the debt servicing ratio to around $70 \%$. Bankruptcy reorganization is an economical and practical way to relief all parties involved in the crisis business. As a result of operating this financial activity, the debtor's compensation rate has been greatly improved; the equity value of the investors can be reserved; the reformers has obtained the control of the debtors and the debtors' existing recourses. Second, bankruptcy reorganization can largely reduce the cost of communication when all parties involved in this crisis company try to negotiate. Bankruptcy reorganization can be efficient at solving debtor's external liabilities, which is a one-time solution to the debtor's debt difficulties. According to the bankruptcy law, during the reorganization procedure, the creditor could not exercise their right if the creditors fails to declare the creditor rights at first. Bankruptcy law monitors the creditor and debtor to apply for the debt right in case any mistakes and the law also guarantees that the creditors and debtors had all fully declared their request before the reorganization plan started to wrote and exercised. The whole standard process can largely reduce the cost of communications between the debtors and creditors. The chance of making any mistakes during the communication can be greatly reduced as well.

Third, once the bankruptcy reorganization approved by the court, it has a strong stability and was very effective. The reorganization plan was passed by the voting groups involved in the plan and they need to apply to the court after negotiation and voting. The plan would start to take effect after it was being approved by the court. The court overviewed all the requests from the debtors and creditors and made decisions based on bankruptcy law. Compared to other financial activities used to help the bankrupt company, the bankruptcy reorganization is more reliable and effective because it is backed by the bankruptcy law.

However, there are still some risks for the debtors because in reality each party only focus on their own interests. Senior creditors, such as banks, expected the company valuation to be low since those credits may get a higher proportion of the reorganized company when the valuation is lower. On the other hand, lower level creditors, such as suppliers may expect a higher company valuation because those creditors could start their full payment only after all the senior claimant finished their money request.

\section{Benefits and Risks for the stock holders}

Regarding to the company's shareholders, there are lots of benefits if the company reorganization is implemented. Main benefit that the company is expected to have a better future after company reorganization. Bankruptcy reorganization is designed to help enterprises which were in a financial crisis back to normal economic condition. Thus, if a company was about to embark on organization reorganization, it would be considered as a good news to the stock market. Good news can lead stock price to rise because if more people want to buy a particular stock, its market price will increase. 
Conversely, if more people want to sell a stock, its price will fall. This relationship between supply and demand is tied into the type of news reports that are issued at any particular moment. Positive news will normally cause individuals to buy stocks. Why do stock prices change following news reports? Good earnings reports, increased corporate governance, new products and acquisitions, as well as positive overall economic and political indicators, translate into buying pressure and an increase in stock price. In China, a stock will be named as "ST", special treatment stock, when the company experienced two losses for two consecutive years; a stock will be named as "*ST", serious special treatment stock when the company experienced losses for three consecutive years or the company is expected to have a strong business uncertainty or to go to insolvency. Shanghai Stock Exchange brings in new delisting rules. (2013). This types of company which had a delisting risk may stop trading at any time. In the case of nuclear titanium dioxide company, Nuclear Titanium Dioxide Company became one of these seriously dangerous company once. However, after executed the reverse merger, this company finally went back to normal. On December 25th, 2012, nuclear titanium dioxide company pronounced that they submitted an application that they would withdraw the warning of delisting to the Shen Zhen stock exchange and waited for the approval from this stock exchange. According to Chinese stock market regulations, this stock was on a suspension for one day at 26th, 2012. The abbreviated form of this security changed from "*ST Titanium White" to "Nuclear Titanium White" and the stock code of this company, 002145, remained the same. The daily stock price increase limit changed from 5\% to $10 \%$. After the company reorganization, The Nuclear Titanium Dioxide Company's stock price went up about 9.15 Yuan after the resumption of trading. The amount of the price rise is around 9.98\%. Their expected profit in 2012 was from 1million to 6 million Yuan. * ST Titanium Dioxide finally changed its old name to nuclear Titanium Dioxide. Its stock price grew sharply after trading halt for a period. (2012)

However, there still risks regarding this financial activity. The primary risk is that the company's stock might be diluted, when a company experienced a bankruptcy, normally bond holders had priority over stock holders regarding reclaiming their rights. Paying back to the debts and introducing of the reform company were able to dilute the shares of the existing shareholders. Moreover, small shareholders had even higher risks because they were lacking of the right of managing the company. For example, the nuclear titanium dioxide company, after major shareholders China Cinda sold the stocked market, stock market is very unstable on an extremely low price. The stock price decreased sharply because the Titanium Dioxide Company split itself froth stated owned company which used to be its enterprise's strongest backing. Thus, small shareholders suffered the most due to this financial activity.

\section{How Employers would be affected by the Company Overhaul}

In common bankruptcy reorganization implementation, those existing workers will have to leave the original company. But in this case, the way the management team arranged those workers were different. Because the Titanium Dioxide Company was in a desert, employers would not able to find a new job easily when they were unemployed. Also, many of the parents of those workers used to be the national pillars in this Country. They contributed a lot to the society. Thus, management team of this reverse merger tried best to guarantee those workers' occupation.

\section{Conclusion}

Bankruptcy reorganization has became one of the most famous financial tools to help companies who were facing financial crisis to go back to health economic condition and to achieve a maximum financial results. Liu (2015)

This paper summarized the bankruptcy reorganization's benefits and risks regarding to the company owners, the private company creditors, employers, debtors, main stock holders and small stock holders. Bankruptcy reorganization of stated owned company is not only about a business regarding a private company buying a shell but also a financial activity related to deepen the reform of economy system, maintain social stability and stated multiple-layer stated owned company social responsibilities. A successful bankruptcy reorganization should properly handle the interests of company employers, small and large stock holders and company creditors. 


\section{Reference}

[1] Liu, H.G. (2010).Case study on Bankruptcy of Listed Company-Take the Case of Nuclear Titanium Dioxide for Example. Lanzhou University. (In Chinese)

[2] Wang, C.C. Cao, Y. Zhang, L.X. (2011).Research on the Bankruptcy and Reorganization Model of Group Listed Companies, Economic Review. (In Chinese)

[3] Shanghai Stock Exchange brings in new delisting rules. (2013 January 4). China Daily. Retrieved from

[4] http://www.chinadaily.com.cn/china/2013-01/04/content_16082355.htm.

(In Chinese)

[5] Xia, T.X. (2016). The Nuclear Titanium Dioxide, how a company recovered from serious financial crisis. 21JINGJI. Retrieved from http: //news.21so.com/2016/hongguan_516/1415864.html. (In Chinese)

[6] Feldman, D. N. (2006). Reverse mergers: Taking a company public without an IPO. Bloomberg Press.

[7] * ST Titanium Dioxide finally changed its old name to nuclear Titanium Dioxide. Its stock price grow sharply after trading halt for a period. (2012 December 27th). Finance.ifeng.com. Retrieved from

http://finance.ifeng.com/a/20121227/7488817_0.shtml

[8] Lin, J. Y. (2004). Lessons of China's transition from a planned economy to a market economy (pp. 1-45). Leon Koźmiński Academy of Entrepreneurship and Management.

[9] Why do stock prices change following news reports? Retrieved from

http://www.investopedia.com/ask/answers/155.asp

[10] Song, H.X, Han, B. (2008). Research on the Military Enterprises' Bankruptcy Reorganization. China Economist, (5), 75-76. (In Chinese) 